Journal of Contemporary Research in Business, Economics and Finance

ISSN: 2641-0265

Vol. 3, No. 3, pp. 70-83.

2021

Publisher: Learning Gate

DOI: 10.33094/26410265.2021.33.70.83

(C) 2021 by the authors; licensee Learning Gate

\title{
The Moderating Role of Geographical Diversification among the Nexus of Institutional, Power and Space Factor on Economic Geography
}

\author{
Ola Aleksandra \\ University of Lodz, Poland. \\ Email:Ola.Alek@uni.lodz.pl
}

Received: 22 March 2021; Revised: 18 June 202 1; Accepted: 15 July 202 1; Published: 9 August 2021

\begin{abstract}
The present paper aims to explore the relationships among the institutional factor, power factor, space factor and economic geography in Poland. The goal of the study also consists of the examination of the moderating role of geographical diversification among the nexus of institutional factor, power factor, space factor and economic geography in Poland. The data has been gathered by using primary data collection methods and used survey questionnaires for data collection along with simple random sampling to select the respondents and PLS-SEM for data analysis. The results revealed that institutional factor, power factor, space factor have a positive association with economic geography in Poland. The outcomes also concluded that the geographical diversification is moderating among the nexus of institutional factor, power factor, space factor and economic geography in Poland. These findings are suitable for the regulators that they should focus on institutional power and space factor that would improve the economic geography in Poland.
\end{abstract}

Keywords: Geographical diversification, Institutional factor, Power factor, Space factor, Economic geography.

\section{Introduction}

In recent years, economic geographers used ideas from structural economics and economic sociology to explain regional growth mechanisms in an increasingly globalized economy. Institutional economics illustrates the social background of urban existence and the complex evolutionary essence of economic growth, offering geographers interested in the form of regional development viewpoints in social and institutional conditions. It is beneficial in moving away from the atomist, and logical vision of the neoclassical economy, which on the one side restricts economic decision-making to the answers of utility-maximizers and on the other hand reduces and determinists the tenor of a great deal of Marxist thinking in which there is no meaning of agency. Institutional prospects illustrate the role of social and cultural factors within regions in influencing trajectories of economic growth and regard localities and regions rather than passive arenas for capital creation as active participants in economic development. With regard to regional development strategy, various geographers used institutionalism as a way to open the "third" between neoclassical market determinism, believing that in the longer term, market forces minimize regional inequalities.

In economic geography and other social sciences, such as economics and sociology, a contentious topic has appeared over the past decade based on the question what research programme, core emphasis and methodology and inclusive of modern economic geography. Studies proposed that modern economic geography has emerged (Boschma, Coenen, Frenken, \& Truffer, 2017; Morgenstern, 2020). This autoproclaimed modern economic geography provides a fascinating economic outlook on typical geographical distribution and balancing questions, focused on the study of increased sales and transport costs as well as other trade interdependencies. Yet a systematic study programme cannot be established as a foundation for economic geography because "Nearly as much of the fact they research is overlooked 
as the old trade hypotheses. This method is best classified as geographic economy following the recommendation of literature (Kamal \& Sundaram, 2019; Sandoval, Robertsdotter, \& Paredes, 2017).

Geographical diversification can be characterized as the extension of a company to many locations. Geographical diversification, in particular, helps businesses to seize future business development prospects and to stabilize average operating returns in several market areas with distinct economic factors, natural environments and laws. Previous research has explored the beneficial influence of geographical diversification on firm value focused on the theory of internalization, capital theories and the new theory of portfolio but there does not seem to be any study of the moderating function of geographical diversification in relation to the relationship between CSR and firm value. A company's wish to pursue ways to use intangible properties on imperfect markets was the initial catalyst for regional diversification. In other terms, businesses may raise their valuation by the use of immaterial properties in many markets. In addition to this point of view, the corporate learning principle which primarily claims that the previous learning of a firm allows applying and collect new and relevant information, also emphasizes that scattered units within an organization will help the corporation develop its intangible assets, such as knowledge base, future capability and expertise in several places (Van den Burg, Aguilar-Manjarrez, Jenness, \& Torrie, 2019; Xu, Yang, Hou, Lu, \& Liu, 2020).

In the economy, there are many industries. The fusion of both fields is known as economics. Initially, both industries assist the market and in the second process, gain economic support. If the country's economy stays steady or on the development road, the effects on whole segments of the market would be favorable. This paper is targeted at Poland's geographic economy. Poland was an ordinary nation with a GDP growth rate of 4.8 per cent in 2019. There is a positive connection between the world's economy and all modes of growth in the country. Suppose you may provide a close view of the country's geographical growth. He would have to look for development in the national economy. In the current period, all economic and regional changes need to be discussed urgently. Geographical growth is becoming a term. Any country's ultimate objective is to improve its quality of living. The per capita income is one of the calculating instruments for assessing living conditions. The actual state sector plays a key position in the economy and is often considered to be one of the country's fundamental needs. If the country economy is increasing, it would have a positive effect on the country's whole project of geographical growth.

The creation of the structural viewpoints in economic geography and regional development studies represents the growing involvement of social sciences in institutionalism. The claim that the larger structural structures underlying economic processes are critical in contrast to the historical propensity for economic geography to adopt conventional economics to abstract "economic" from its wider social, political and cultural contexts. Although orthodox economists believe that the market is rationally driven and controlled, institutions claim that broader social norms stabilize the economy. Economic geographers have also drawn on a related collection of economic, sociological ideas which underline that economic processes are rooted in social relations. Although there is no space for a more thorough review of such forces here, studies proposed that there is a propensity to uncritically import and deploy terms from economic sociology and structural economics - for example 'embeddedness' - without clearly describing or stating their significance. Given these remarks, it is worth taking a more in-depth look at some of the initial principles of the institutional economy (Aguilera-Caracuel \& Guerrero-Villegas, 2018; Zúñiga-Vicente, Benito-Osorio, Guerras-Martín, \& Colino, 2019). The growth in the GDP also shows the geographical improvement in the country because if the country is geographically developed, it could be able to produce significant GDP for the country. As shown in Figure 1, the development in GDP from the first quarter of 2017 is the evidence in the geographical development in Poland while it is reduced after 2019 due to Covid-19. These figures are shown in Figure 1. 


\section{Poland GDP Chart}

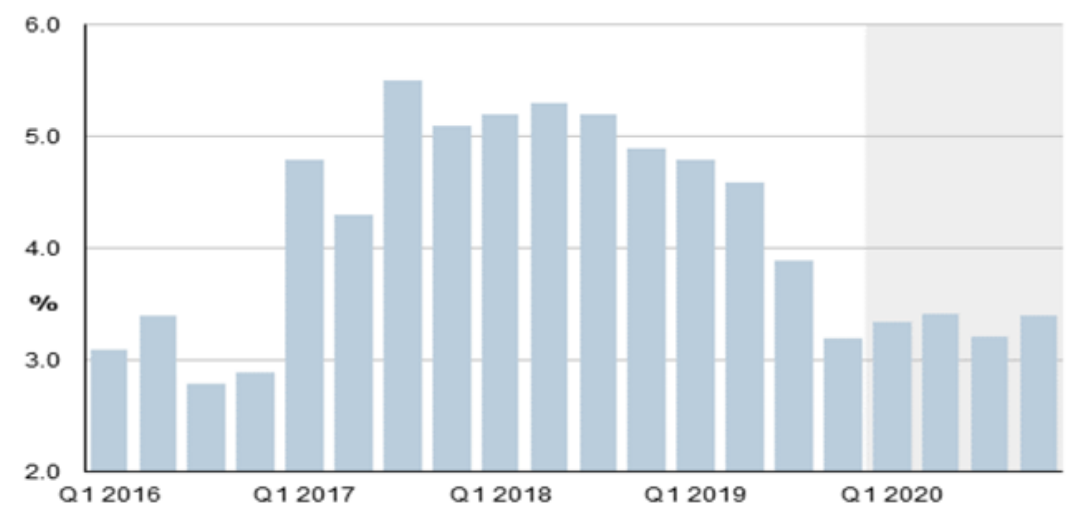

Figure-1.

Poland GDP chart.

As a balance in any country, export and import are considered as one of the positive indicators towards the country economy. The more exports will support the country economy, which in turn will enable the country to spend more on the infrastructure and other related geographical developments projects. The import put the negative impact on the balance of payment, and geographical infrastructure is one of the significant reasons of high import in the country. The major import countries are given in Figure 2 that is shown the geographical importance for import and export of the country.

\section{Poland major import sources (2017)}

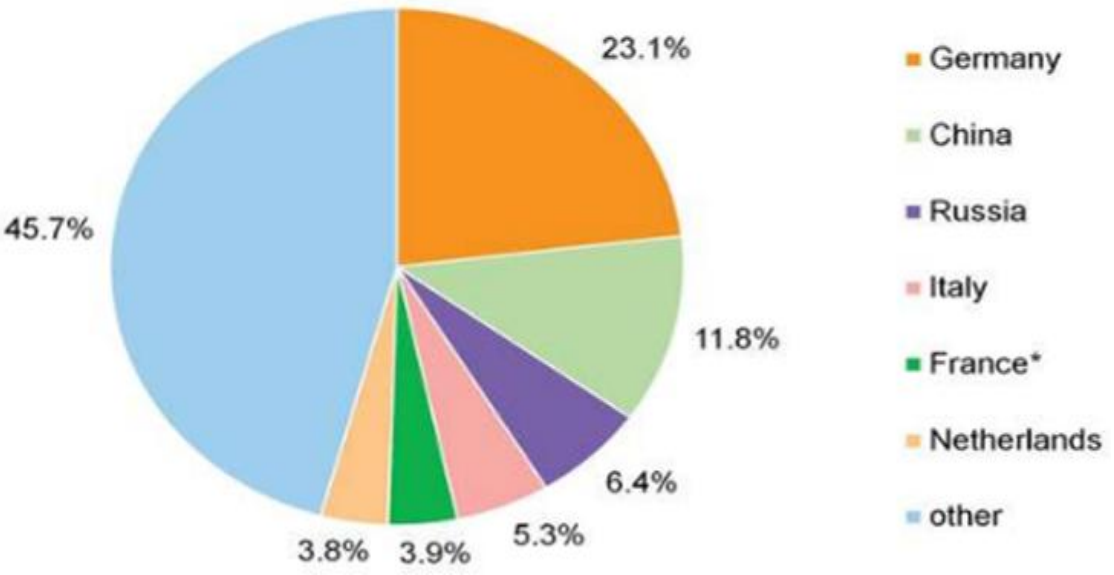

Figure-2.

Import chart of Poland.

\section{Literature Review}

The introduction of institutional theories is part of a broader change in economic areas, where the social and cultural aspects of economic activity have been given greater importance. In the sense of regional development, and institutional perspective reflects on how the internal features of an area will promote or impede economic growth. Latest assertions concerning the transition to the knowledgebased economy have strengthened the call to institutional ideas. Conceptions about creativity as a socially equitable and collaborative mechanism have contributed to new arguments regarding the value 
of localized learning in the creation of strategic regional advantage (Bawaneh, 2020; Commission, 2019; Munusamy \& Wong, 2007). The main point is that in particular, the transfer of implicit information types involves regular social contact and consequently near geographical proximity between companies contributing to new forms of spatial clustering in knowledge-based industries. It has contributed to a new emphasis on the regional level as the central location for social engagement and the development of information. Although we accept the idea that the market is socially rooted and therefore economic existence depends on the direction and meaning, here we disagree with some of the aspects in which institutionalism was understood and implemented within economic geography. In specific, our criticism focuses on two interrelated subjects. First of all, the neglect of power and politics in accordance with future intra-regional divisions and the consequences of broader unequal growth and political-economic control systems. Second, we are dismissive of the propensity to reify the region as an objective of scientific investigation and a place of political action across other spatial scales. Some studies indicate that regions are viewed almost as strategic agents - primarily by terms such as the 'learning zone' (Mao \& Wang, 2016; Philip-Mccann, 2017). The adoption of institutionalism by economic geographers was provisional and incomplete, perhaps indicative of the very vague character of institutionalism, particularly in comparison with neoclassical economics' analytic elegance and tractability, with its ability to make straightforward forecasts and the 'fresh economic geography'. Our key concern is the narrow way in which some facets of institutionalism have been associated with instrumentalists on the need for regions to compete by continuous learning and creativity in an increasingly globalized economy. This instrumentalist perspective seems somewhat contradictory with the ancient structural practice of seeing the economy as a structure centered on strength, wisdom and values. Instead, we argue that structural experience is properly incorporated into a more complex and relational methodology which does not render any scale important but treats economic growth as an out-and-out and debated mechanism functioning on various geographical scales. From this point of view, regions are created and repeated by the behavior of unique social groups and institutions that function within larger accumulative and regulatory frameworks. This segment explores the origins of structural economics and the institutional 'turn' of economic geography. The third segment criticizes the institutional work of economic geography, which illustrates the inadequacy of room and power problems. In the fourth section, we stress the need to include institutional insights in a more dynamic, relational approach to regional development and try to determine its implications for empirical research and policy (Inkinen \& Kaakinen, 2016; Kirdina-Chandler, 2019).

While the literature takes economic geography closer to the central principles of neoclassical economics, literature also proposed another radically different course for economic geography, building on other social sciences' definitions and theories. Literature also suggests economic that geography will no longer 'fire the imagination' of researchers. They, therefore, call for a crucial reflection and renewal of the core aims, principles and approaches in this area. The reactions to their contribution encouraged a dialogue, some of which were published in a special edition of Antipode in 2001. Unfortunately, disciplinary-political points, views and statements control this dialogue. It focuses fundamentally on the issue of whether economic geography should be strongly related to economics or oriented towards social, political and cultural research. In particular, an increasing concern both in the cultural component of economic ties and in cultural studies economic issues (Brouder, 2017).

On the other hand, the literature also suggests a cultural change from the neoclassical economy; their critics stress the similarities between economic theories and the significance of them as the basis for economic geography. This controversy is partially built on false dualism, such as economics versus sociology and quantitative versus consistency methodology. In our opinion, this controversy is ambiguous since it combines the normative accounts of the ethical ramifications of the field with epistemological and analytical claims. The discussion is, therefore, quite misdirected when it seeks to distinguish these inseparable economic and social elements. If economic geography should be economized or cultivated cannot be the deciding issue. Instead, economic and social interconnections are 
central. They are aspects of the same scientific truth that must be studied in a conversation, rather than in collective isolation and reductionist priority (Deng, Lu, \& Zhao, 2021; Rahmouni, 2020).

Based on past literature, three wide-ranging model approaches to economic geography have evolved sequentially over time. This is named "nderkunde" (i.e. geographical definition and synthesis research), regional (or spatial analysis) science and related economic geography. While we speak about this change from a German spatial viewpoint, our goal is not to promote a debate on the condition of contemporary economic geography in Germany. We are, however, persuaded that the distinguished paradigmatic methods had an essential impact on how economists have interpreted their profession and how economic geography has been organized in the course of time (Benito-Osorio, Colino, Guerras-Martín, \& ZúñigaVicente, 2020; Deng et al., 2021).

The insights we derive from the discussion serve as the foundation for creating the novel methodological paradigm we term relational, economic geography. Literature opines that recent developments in economic geography do not take place progressively, as established definitions are merely strengthened or revised. A wealth of different insights, approaches and conceptions has been developed since the late 1980s, involving persuasive ideas that can serve as the foundation for reconceptualizing economic geography. The results of this are so significant that we perceive them as paradigmatic and as constituting the second transformation. They develop as stages of vigorous debate, which gives rise to new claims that in turn provide an impulse for a transition to a new viewpoint. Over time, this is dominated by agreement and 'fair reason'. The second transformation is because it parallels a first significant shift to regional science in Germany and is characteristic of another move from regional science to a modern paradigm we refer to as relational, economic geography (Boschma et al., 2017; Knight, Kumar, Wójcik, \& O’Neill, 2020).

Geographically dispersed enterprises need to respond to various societal, political, fiscal, and customer demands in each regional market. This task enables corporations' ability to develop awareness and resources to accommodate a range of stakeholders in a variety of environments. Furthermore, past scholars viewed regional diversification not only as a way to achieve improved economic results and minimize risk but also as a tactic to maintain competitive advantages. The global diversification of businesses allows their products more recognizable. In essence, customers think about and familiarize themselves with the brand. Indeed, one of the critically intangible properties that enhance shareholder capital is the strategic advantages achieved by regional diversification, market recognition and brand credibility. Some researchers also argued that brand recognition created by business visibility and contact with customers in many places would enable companies to boost revenues and start new businesses (Park, Song, \& Lee, 2017). These strategic advantages from global diversification (wider stakeholder needs, improved market recognition and a better brand reputation) may be essential in the partnership between CSR and corporate risk. Literature also indicated a positive influence from brand recognition on the relationship between CSR and product appraisal, while another analysis explored the effects of brand credibility on ads for social responsibility for fair trade coffee. The latter analysis found that coffee products with higher brand recognition are better off than coffee products with less familiarity. In addition, some other studies proposed that a brand with a reputation for good CSR business would contribute to greater leverage on the sector. Therefore, it is necessary for restaurant companies who use geographical diversification as the primary strategy to widen their market share to consider the impact of the degree of geographic diversification. However, there appears to be no research on the moderating impact of geographical diversification on the partnership between SRC and company risk (Lupia \& McCubbins, 2000; Wakaisuka-Isingoma, Aduda, Wainaina, \& Mwangi, 2016). The current research indicates that geographical diversification plays a positive role in improving the influence of positive CSR programmes on corporate risks mitigation (Hassink \& Klaerding, 2012; Kang $\&$ Lee, 2014).

An organization, expertise and strategic relationships between organizations and their surroundings provide a path forward to help us consider these complicated, but essential issues. In order to better understand the interplay between $\mathrm{MNE}$ and its geographical climate, incorporation of a 
discussion of company operational problems with the characteristics of the sub-national area is necessary. This is also timely, as the effect that MNEs evolving approach is rightly being considered to be one of IB's 'big questions' (Aguilera-Caracuel \& Guerrero-Villegas, 2018; Simandan, 2011). Therefore, a specifically geographical perception of the MNE, which focuses at the same time on the conceptions of location, room and organization as well as on spatial transaction costs and information properties, provides a technically distinctive and empirically traceable approach to these problems. Literature also proposed that in last decade award-winning paper that its position in its OLI model has moved from being only a debate on cost minimization to concentrating 'on how to improve the strategic advantage of companies by learning and clusters: and on cutting cross-border transaction costs in a dynamic MNE environment'. However, such concerns cannot be isolated from distance issues and IB most frequently perceived this in terms of the distance between the house and the host country. However, according to geographers, distance is a multidimensional structure that corresponds to societal, administrative, geographical and economic distance (Boschma et al., 2017; Kamal \& Sundaram, 2019; Wills, 2019). "The economies of territories thus represent how they are "inserted" into the market space of companies, either as a locus of essential functions explicitly or indirectly, by customer-supplier ties. The dynamic concept of distance ensures that MNEs also face so-called international liability which has a diverse effect on the position of the MNEs and investment decisions. Indeed, it has been noticed empirically that the cultural, administrative and geographical distances not only contribute to lower cross-border expenditure but also that different distance notions influence the FDI markets in various ways and the productivity in a quest for FDI. This special issue of the Journal of Economic Geographic's intends to open these specifically regional facets of multinational and multiple actions from various viewpoints to encourage a fertile exchange of ideas and to increase public understanding of the potential observations and pathways to further interdisciplinary revision of all three kinds of literature (Ballas, Dorling, \& Hennig, 2017; Child \& Barnes, 2019; Knight et al., 2020). This position, room and organization subject are strongly resembling the papers in this issue in terms of the problems discussed and the facts gleaned. The thematic framework of position, space and organization is more of a continuum rather than a shared exclusive group, and we will gradually travel along the continuum across the series of articles. Introduction: economic and international market geography Studies also explores the connection between entrepreneurship and firm founding actions and the local cluster framework at the companies may demonstrate convergence at regional-industry level (Garrido-Prada, Delgado-Rodriguez, \& Romero-Jordán, 2019; Morgenstern, 2020). Their research reveals that the strength of a cluster in the presence of similar industries is a crucial determinant for the creation of new facilities through monitoring these characteristics. Moreover, this observation often includes numerous plant companies pursuing new institutions in fields in which they currently work, as well as for new startups. The hypotheses derived from the above debate are as under:

H1: Institutional factors are significantly positively associated with economic geography of Poland.

H2: Power factors are significantly positively associated with economic geography of Poland.

H3: Space factors is significantly positively associated with economic geography of Poland.

H4: Geographical diversification act as a moderator on the association between institutional factors and the economic geography of Poland.

H5: Geographical diversification act as a moderator on the association between power factors and the economic geography of Poland.

H6: Geographical diversification act as a moderator on the association between space factor and economic geography of Poland.

\section{Research Methods}

The goal attached with the present paper is to explore the relationships among the institutional factor, power factor, space factor and economic geography in Poland along with the examination of moderating role of geographical diversification among the nexus of institutional factor, power factor, space factor and economic geography in Poland. The data has been gathered by using primary data 
collection methods and used survey questionnaires for data collection along with simple random sampling to select the respondents. The employees of geographical planning department are the respondents of the study and questionnaires have been sent to them by personal visit. A total of 510 surveys were sent during the first visit, but only 280 were returned that represented about 54.90 per cent response rate. Furthermore, PLS-SEM has been executed by using the smart-PLS, an effective analysis tool for data analysis due to purpose of the study is hypotheses testing along with complex model has been taken by the study (Sarstedt \& Cheah, 2019).

The variables that have been taken by the study include one moderating variable named as geographical diversification (GD) that has eight items while economic geography (EG) has been used as a predictive variable that also has eight items. In addition, institutional factor (IF), power factor (PF), space factor (SF) have been taken by the study as predictors that have eight, six and five items, respectively. These variables, along with their nexus, are shown in Figure 3.

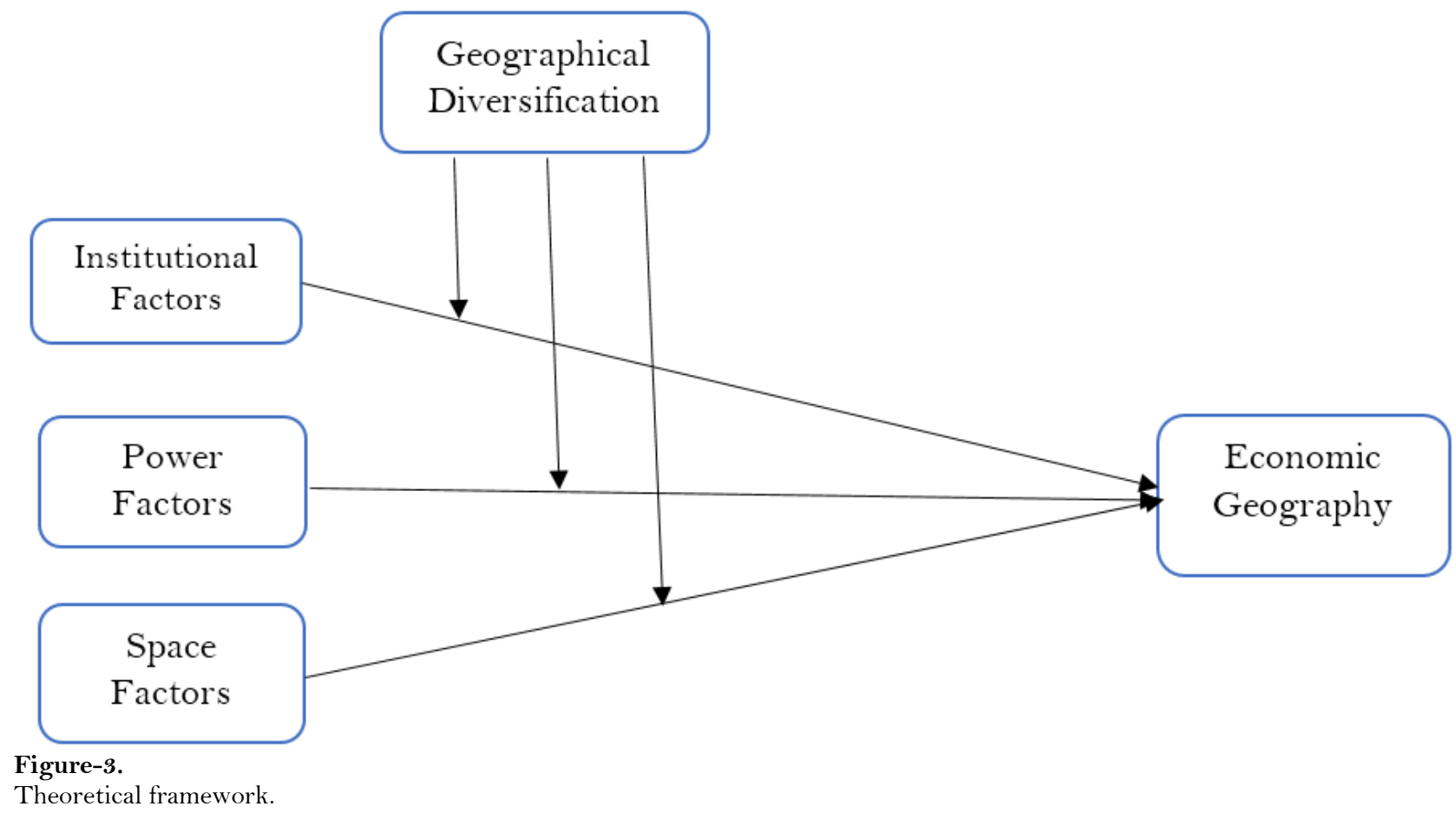

\section{Findings}

The findings have shown the measurement and structural model assessment by using the Alpha, loadings, composite reliability (CR), AVE, and Heterotrait Monotrait (HTMT) ratio and path analysis for hypotheses testing. Firstly, convergent validity has been examined that is the part of measurement model assessment and show the association among items. The values of Alpha and CR are more than 0.70, while loadings and AVE are larger than 0.50. These are pieces of evidence of valid convergent validity and high correlation among items. These are highlighted in Table 1 and Figure 4.

Secondly, discriminant validity has been examined that is also the part of measurement model assessment and show the association among variables. The values of Heterotrait Monotrait (HTMT) ratios are lower than 0.90. These are shreds of evidence of valid discriminant validity and low correlation among variables. These are highlighted in Table 2. 
Table-1.

Convergent validity.

\begin{tabular}{|c|c|c|c|c|c|}
\hline Constructs & Items & Loadings & Alpha & CR & AVE \\
\hline \multirow[t]{7}{*}{ Economic Geography } & EG 1 & 0.602 & 0.871 & 0.901 & 0.567 \\
\hline & $\mathrm{EG} 2$ & 0.805 & & & \\
\hline & EG3 & 0.803 & & & \\
\hline & EG4 & 0.666 & & & \\
\hline & EG5 & 0.824 & & & \\
\hline & EG6 & 0.769 & & & \\
\hline & EG8 & 0.776 & & & \\
\hline \multirow[t]{8}{*}{$\begin{array}{l}\text { Geographical } \\
\text { Diversification }\end{array}$} & GD1 & 0.677 & 0.932 & 0.929 & 0.621 \\
\hline & $\mathrm{GD} 2$ & 0.791 & & & \\
\hline & GD3 & 0.820 & & & \\
\hline & GD4 & 0.804 & & & \\
\hline & GD5 & 0.826 & & & \\
\hline & GD6 & 0.793 & & & \\
\hline & GD7 & 0.783 & & & \\
\hline & GD8 & 0.803 & & & \\
\hline \multirow[t]{8}{*}{ Institutional Factor } & $\mathrm{IF}_{1}$ & 0.903 & 0.948 & 0.957 & 0.735 \\
\hline & $\mathrm{IF} 2$ & 0.901 & & & \\
\hline & IF3 & 0.841 & & & \\
\hline & IF 4 & 0.868 & & & \\
\hline & IF 5 & 0.875 & & & \\
\hline & IF 6 & 0.713 & & & \\
\hline & IF 7 & 0.867 & & & \\
\hline & $\mathrm{IF} 8$ & 0.873 & & & \\
\hline \multirow[t]{6}{*}{ Power Factor } & $\mathrm{PF} 1$ & 0.860 & 0.904 & 0.927 & 0.683 \\
\hline & $\mathrm{PF} 2$ & 0.844 & & & \\
\hline & PF3 & 0.857 & & & \\
\hline & $\mathrm{PF} 4$ & 0.873 & & & \\
\hline & PF5 & 0.879 & & & \\
\hline & PF6 & 0.616 & & & \\
\hline \multirow[t]{4}{*}{ Space Factor } & $\mathrm{SF} 1$ & 0.925 & 0.951 & 0.965 & 0.873 \\
\hline & $\mathrm{SF} 2$ & 0.953 & & & \\
\hline & SF3 & 0.96 & & & \\
\hline & SF 5 & 0.897 & & & \\
\hline
\end{tabular}

Table-2.

Discriminant validity.

\begin{tabular}{l|c|c|c|c|c}
\hline Variables & EG & GD & IF & PF & SF \\
\hline EG & & & & & \\
\hline GD & 0.230 & & & & \\
\hline IF & 0.560 & 0.212 & & & \\
\hline PF & 0.450 & 0.198 & 0.464 & & \\
\hline SF & 0.532 & 0.466 & 0.511 & 0.452 & \\
\hline
\end{tabular}




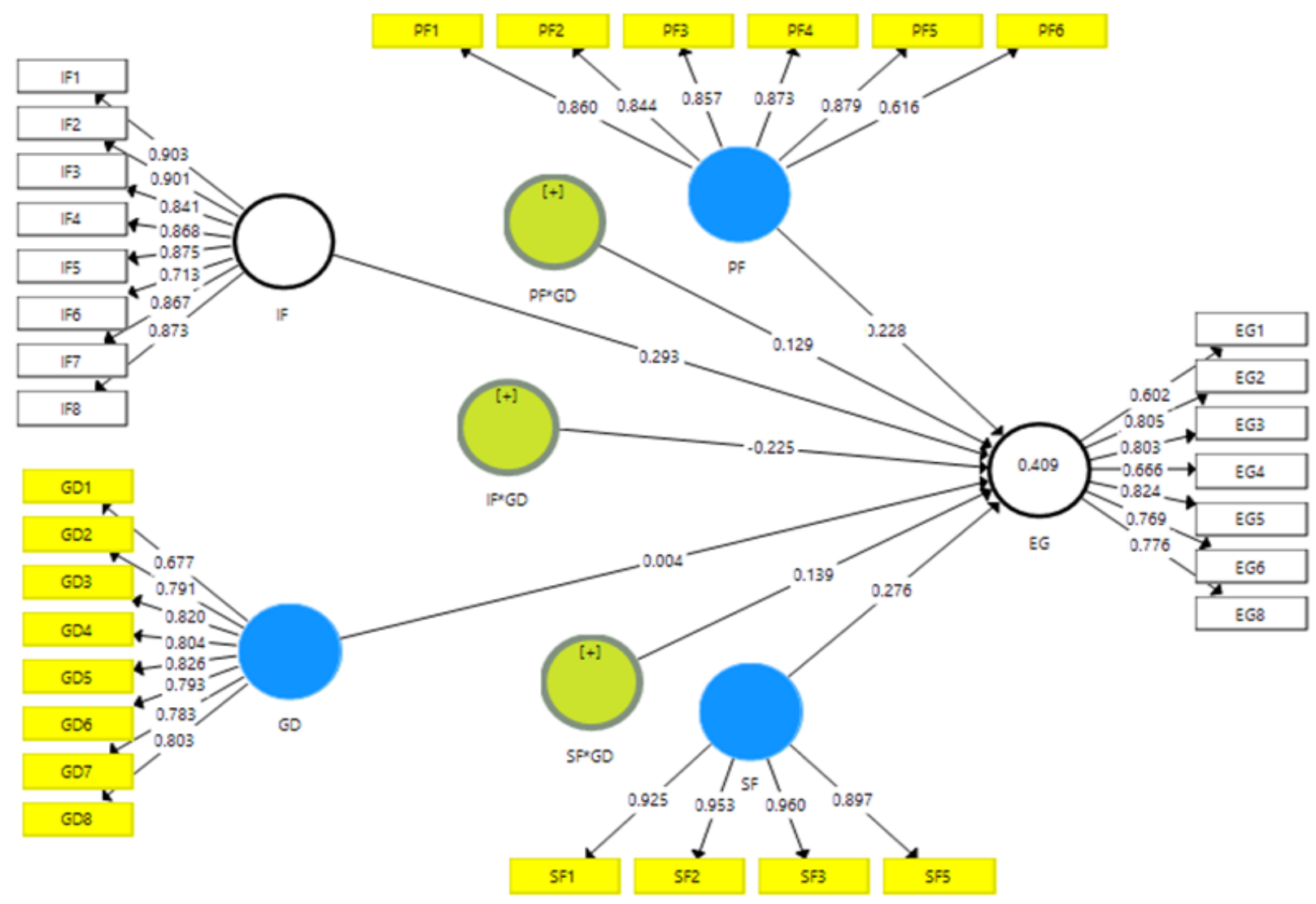

Figure-4.

Measurement model assessment.

Finally, the path analysis has been used for hypotheses testing that is the part of the structural model assessment (in Figure 5). The results of the path analysis revealed that institutional factor, power factor, space factor have a positive association with economic geography in Poland and accept $\mathrm{H} 1, \mathrm{H} 2$ and H3. In addition, the outcomes also concluded that the geographical diversification is moderating among the nexus of institutional factor, power factor, space factor and economic geography in Poland and accept H4, H5 and H6. These links are shown in Table 3.

Table-3.

A path analysis.

\begin{tabular}{l|c|c|c|c|c|c}
\hline Relationships & Beta & S.D. & t-statistics & p-values & L.L. & U.L. \\
\hline IF -> EG & 0.293 & 0.067 & 4.363 & 0.000 & 0.177 & 0.409 \\
\hline IF*GD -> EG & -0.225 & 0.063 & 3.551 & 0.000 & -0.322 & -0.130 \\
\hline PF -> EG & 0.228 & 0.071 & 3.194 & 0.001 & 0.128 & 0.343 \\
\hline PF*GD -> EG & 0.129 & 0.064 & 2.025 & 0.023 & 0.019 & 0.226 \\
\hline SF -> EG & 0.276 & 0.100 & 2.753 & 0.004 & 0.102 & 0.398 \\
\hline SF*GD -> EG & 0.139 & 0.080 & 1.726 & 0.044 & 0.010 & 0.262 \\
\hline
\end{tabular}




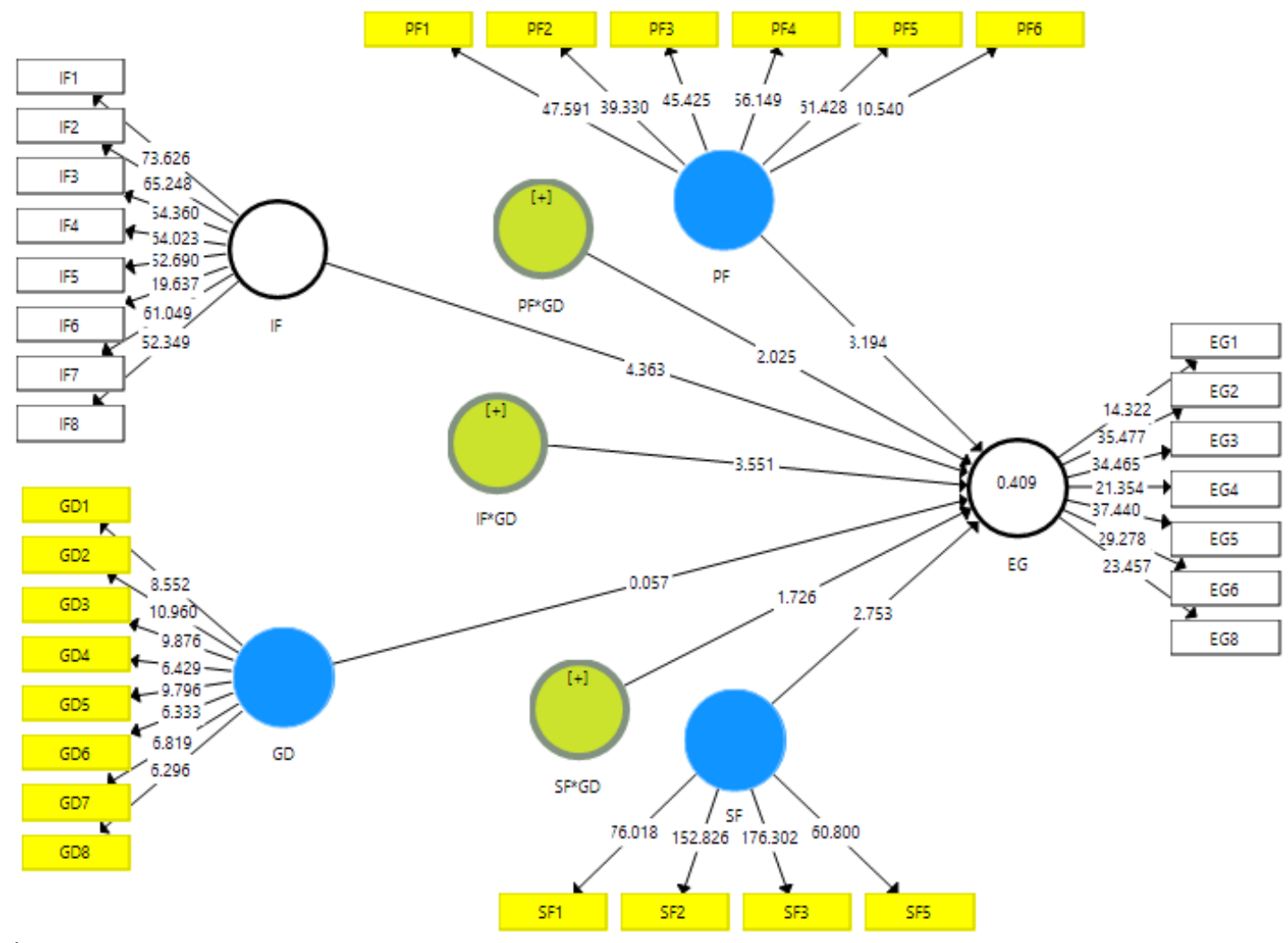

Figure-5.

Structural model assessment.

In Figure 6 the outcomes concluded that the geographical diversification is moderating among the nexus of institutional factor and economic geography in Poland and accept $\mathrm{H} 4$ because the blue line is above the red and green line that is the indication of negative and significant moderation. Figure 6 shows this relationship given below:

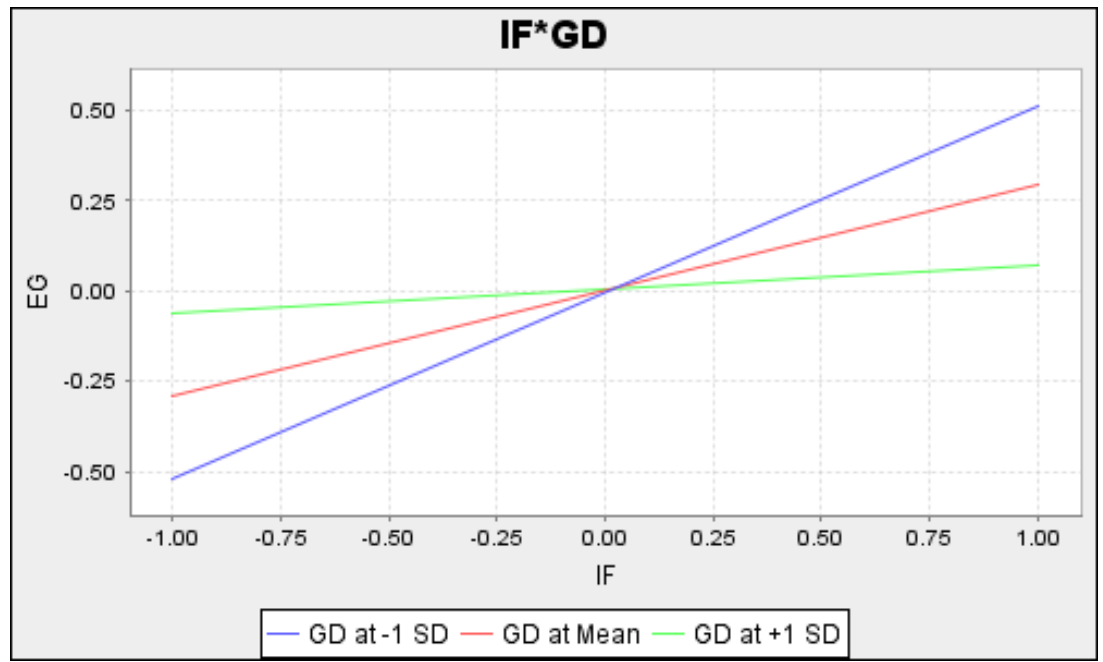

Figure-6.

IF*GD. 
In Figure 7 the results also exposed that the geographical diversification is also moderating among the nexus of power factor and economic geography in Poland and accept H5 because the green line is above the red and blue line that is the indication of positive and significant moderation. Figure 7 shows this relationship given below:

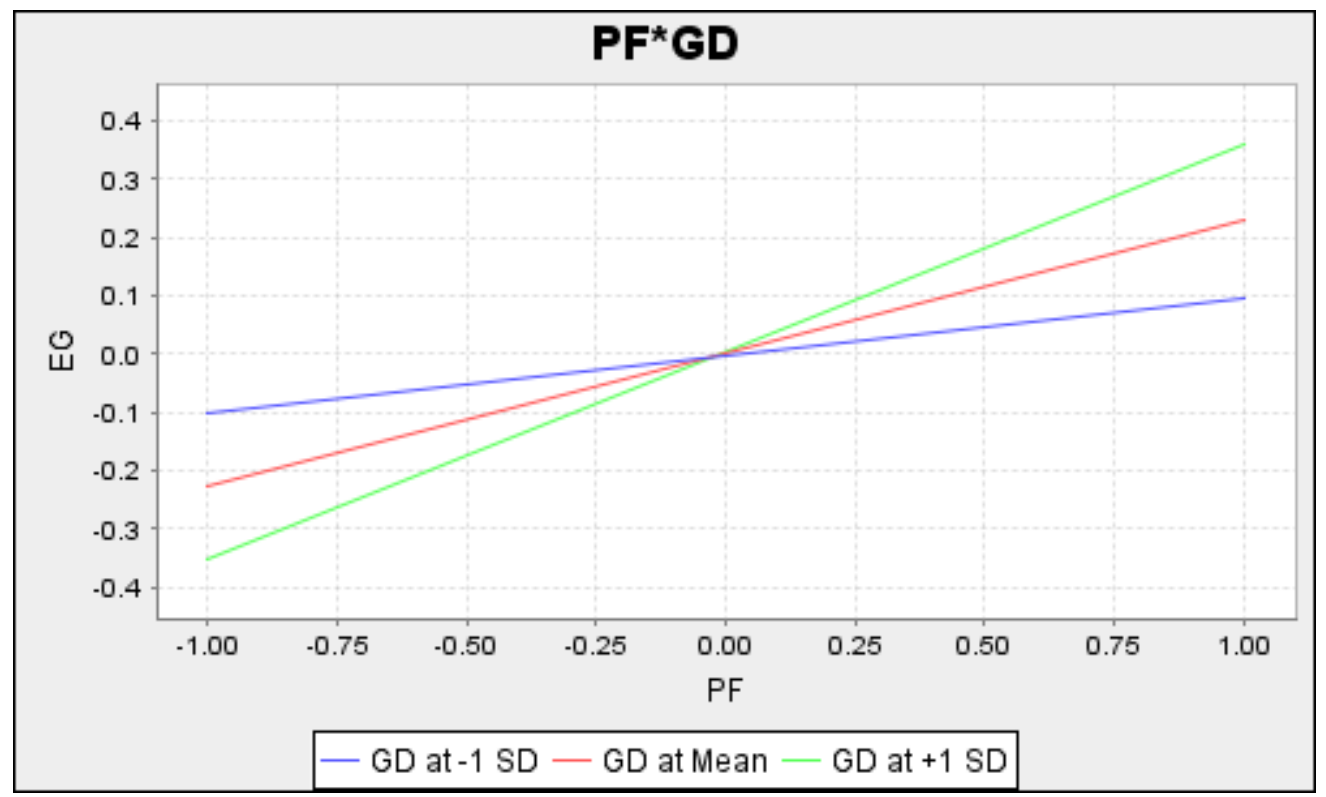

Figure-7.

PF*GD.

In Figure 8 the results also exposed that the geographical diversification is also positively and significantly moderates among the nexus of power factor and economic geography in Poland and accept $\mathrm{H} 6$ because the green line is above the red and blue line. Figure 8 shows this relationship given below:

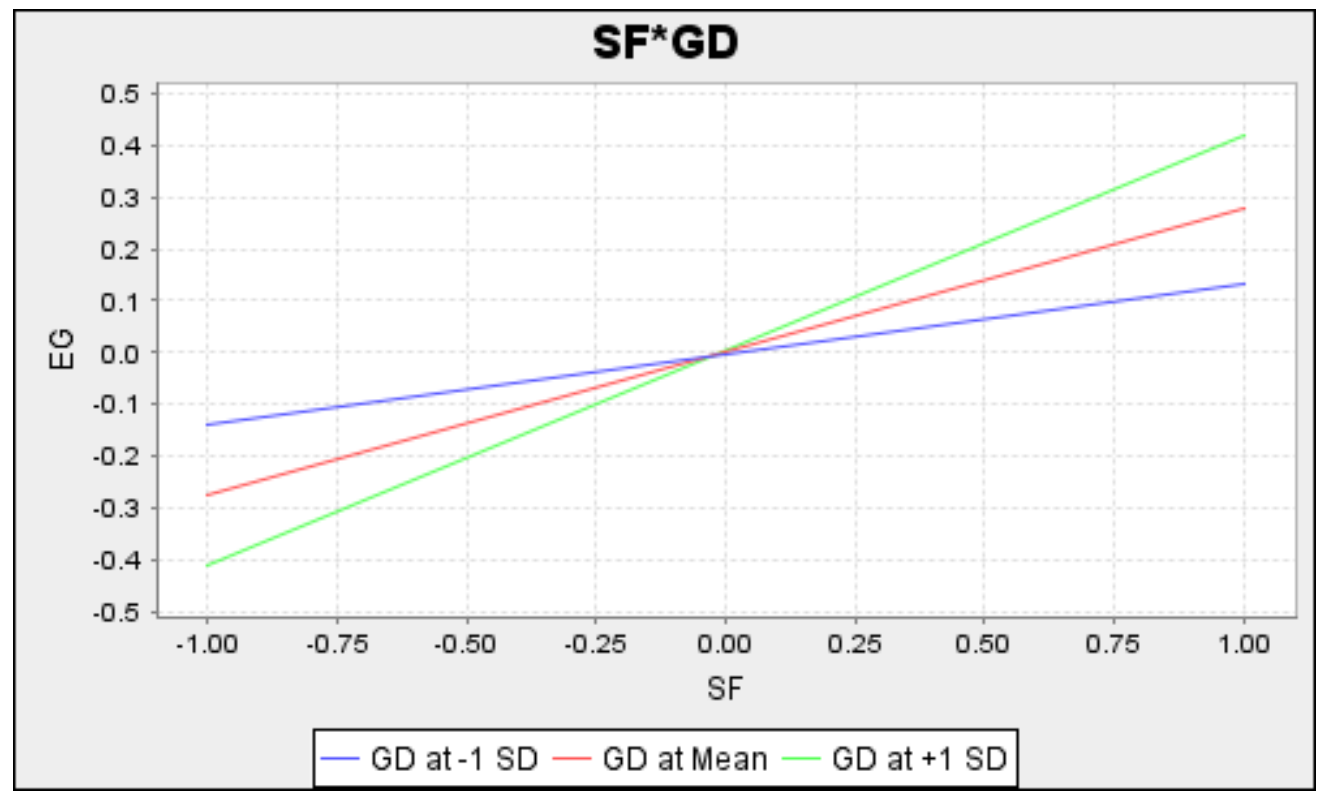

Figure-8.

$\mathrm{SF}^{*} \mathrm{GD}$.

Journal of Contemporary Research in Business, Economics and Finance

ISSN: 2641-0265

Vol. 3, No. 3, pp. 70-83, 2021

DOI: 10.33094/26410265.2021.33.70.83

(C) 2021 by the authors; licensee Learning Gate 


\section{Discussion and Implication}

The results of the study have indicated that the institutional factors are positively linked with economic geography in Poland. These results are in line with the previous studies of Aparicio, Urbano, and Audretsch (2016), which indicates the significant contribution of institutional factors to the economic geography. The results have revealed that the power factors have a positive association with economic geography in Poland. These results agree with the studies of Fally, Paillacar, and Terra (2010) according to which the efficient power factors bring improvement in the economic geography in Poland. The results have indicated that the space factors have a positive association with economic geography. These results are in accordance with the results of past studies of Lawson (2010), which indicate that the improvement in the space factors leads to the improvement in the economic geography. Moreover, the findings of the study have indicated that geographical diversification is a significant moderator between institutional factors and economic geography as it strengthens their mutual association in the context of Poland. These results match with the past studies of Qian, Khoury, Peng, and Qian (2010) according to which the association between institutional factors and economic geography in the presence of geographical diversification. Furthermore, the results have indicated that geographical diversification plays a moderating role between power factors and economic geography in Poland. These results agree with the past studies of Pike, MacKinnon, Cumbers, Dawley, and McMaster (2016) which throw light on the point that the geographical diversification being a significant moderator puts positive impacts on the relationship between power factors and economic geography. In addition, the results have revealed that geographical diversification is a considerable moderator between space factors and economic geography for its positive impacts on their mutual association in the context of Poland. These results are in line with the previous studies of Goetz, Laeven, and Levine (2013) which shed light on the point that the relationship between space factors and economic geography becomes strong with geographic diversification.

The current paper carries out both theoretical and empirical implications. From the perspective of theoretical implications, the study contributes a lot to the literature on geography. The study describes the contribution of efficient institutional factors, better power factors, and effective space factors to economic geography. The study also implies that geographical diversification puts moderating influences on the mutual association of institutional factors, power and space factors, and economic geography. The study also makes empirical implications as it gives a guideline to the economic management of how to improve economic geography with the improvement in institutional factors, better quality power factors, and better space factors and with geographical diversification as a moderator between institutional, power, and space factors.

\section{Conclusion and Limitations}

In short, the paper concludes that the institutional factors are in positive link with economic geography. The study examines that efficient and effective institutional factors bring improvement in economic geography. Moreover, the study analyses that the power factors have a positive association with economic geography. The better the power factors, the better the economic geography. In addition, the improvement in the space factors leads to improvement in economic geography. Besides, the results indicate that geographical diversification is a considerable moderator between institutional factors, power factors, and space factors, and economic geography. Economic geography influences institutional, power, and space factors, and economic geography and also put effects on their mutual relationship of institutional factors, power factors, and space factors and economic geography.

The current study describes the influences of three variables, such as institutional factors, power, and space factors on economic geography. Besides these three variables, several factors are there to influence the economic geography that should be addressed by future academics in their studies. Here in this study, geographical diversification has been used as a moderator between institutional factors, power and space factors, and economic geography while the same can be used as a mediator. Thus, it is expected from future scholars to treat geographical diversification as a mediator between institutional 
factors, power, and space factors and the economic geography. In addition, data used in support of this study has been collected by using only a particular source so it may be limited in terms of comprehensiveness and completeness thus future scholars are required to use more than one source for the collection of data for supporting their study.

\section{References}

Aguilera-Caracuel, J., \& Guerrero-Villegas, J. (2018). How corporate social responsibility helps MNEs to improve their reputation. The moderating effects of geographical diversification and operating in developing regions. Corporate Social Responsibility and Environmental Management, 25(4), 355-372.Available at: https://doi.org/10.1002/csr.1465.

Aparicio, S., Urbano, D., \& Audretsch, D. (2016). Institutional factors, opportunity entrepreneurship and economic growth: Panel data evidence. Technological Forecasting and Social Change, 102, 45-61.Available at: https://doi.org/10.1016/j.techfore.2015.04.006.

Ballas, D., Dorling, D., \& Hennig, B. (2017). Analysing the regional geography of poverty, austerity and inequality in Europe: a human cartographic perspective. Regional Studies, 51(1), 174-185.Available at: https://doi.org/10.1080/00343404.2016.1262019.

Bawaneh, S. S. (2020). Impact of corporate governance on financial institutions? Performance: A board composition case. Asian Economic and Financial Review, 10(1), 54-59.

Benito-Osorio, D., Colino, A., Guerras-Martín, L. Á., \& Zúñiga-Vicente, J. Á. (2020). The combined effects of product and geographical diversification on performance: Evidence in manufacturing SMEs. BRQ Business Research Quarterly, 23(2), 91-106.Available at: https://doi.org/10.1177/2340944420916332.

Boschma, R., Coenen, L., Frenken, K., \& Truffer, B. (2017). Towards a theory of regional diversification: combining insights from evolutionary economic geography and transition studies. Regional Studies, 51(1), 31-45.Available at: https://doi.org/10.1080/00343404.2016.1258460.

Brouder, P. (2017). Evolutionary economic geography: Reflections from a sustainable tourism perspective. Tourism Geographies, $19(3), 438-447$.

Child, E. C., \& Barnes, T. J. (2019). American imperial expansion and area studies without geography. Journal of Historical Geography, 66(3), 43-54.

Commission, E. (2019). Best practices for financial literacy and education at institutions of higher education.

Deng, A., Lu, J., \& Zhao, Z. (2021). Rural destination revitalization in China: applying evolutionary economic geography in tourism governance. Asia Pacific Journal of Tourism Research, 26(2), 215-230.Available at: https://doi.org/10.1080/10941665.2020.1789682.

Fally, T., Paillacar, R., \& Terra, C. (2010). Economic geography and wages in Brazil: Evidence from micro-data. Journal of Development Economics, 91(1), 155-168.Available at: https://doi.org/10.1016/j.jdeveco.2009.07.005.

Garrido-Prada, P., Delgado-Rodriguez, M. J., \& Romero-Jordán, D. (2019). Effect of product and geographic diversification on company performance: Evidence during an economic crisis. European Management Journal, 37(3), 269-286. Available at: https://doi.org/10.1016/j.emj.2018.06.004.

Goetz, M. R., Laeven, L., \& Levine, R. (2013). Identifying the valuation effects and agency costs of corporate diversification: Evidence from the geographic diversification of US banks. The Review of Financial Studies, 26(7), 1787-1823.Available at: https://doi.org/10.1093/rfs/hht021.

Hassink, R., \& Klaerding, C. (2012). Theoretical advancement in economic geography by engaged pluralism: Utrecht University, Department of Human Geography and Spatial Planning.

Inkinen, T., \& Kaakinen, I. (2016). Economic geography of knowledge-intensive technology clusters: Lessons from the Helsinki Metropolitan Area. Journal of Urban Technology, 23(1), 95-114.Available at: https://doi.org/10.4324/97813150986786.

Kamal, F., \& Sundaram, A. (2019). Do institutions determine economic Geography? Evidence from the concentration of foreign suppliers. Journal of Urban Economics, $110(7)$, 89-101.

Kang, K. H., \& Lee, S. (2014). The moderating role of brand diversification on the relationship between geographic diversification and firm performance in the US lodging industry. International Journal of Hospitality Management, 38(4), 106-117.

Kirdina-Chandler, S. (2019). Western and non-Western economic institutional models in time and geographical space. Terra Economicus, 17(1), 1-9.

Knight, E., Kumar, V., Wójcik, D., \& O’Neill, P. (2020). The competitive advantage of regions: Economic geography and strategic management intersections (Vol. 8, pp. 22-32): Taylor \& Francis.

Lawson, V. (2010). Reshaping economic geography? Producing spaces of inclusive development. Economic Geography, 86(4), 351-360.Available at: https://doi.org/10.1111/j.1944-8287.2010.001092.x.

Lupia, A., \& McCubbins, M. D. (2000). Representation or abdication? How citizens use institutions to help delegation succeed. European Journal of Political Research, 37(3), 291-307.Available at: https://doi.org/10.1111/1475-6765.00514. 
Mao, Q., \& Wang, F. (2016). Will Decline in foreign trade reshape internal economic geography? Simulations in an estimated model of the Chinese space-economy. Business and Management Studies, 2(4), 54-69.Available at: https://doi.org/10.11114/bms.v2i4.2018.

Morgenstern, S. (2020). Spending to win: Political institutions, economic geography, and government subsidies. Perspectives on Politics, $18(3), 968-969$.

Munusamy, J., \& Wong, C. H. (2007). Attitude towards advertising among students at private higher learning institutions in Selangor. Unitar E-journal, 3(1), 31-51.

Park, S., Song, S., \& Lee, S. (2017). Corporate social responsibility and systematic risk of restaurant firms: The moderating role of geographical diversification. Tourism Management, 59(5), 610-620.

Philip-Mccann, E. E. (2017). Please cite as follows: Suwala, L.(2013): Multinationals and Economic Geography: Location, Technology and Innovation. Regional Studies, 47(8), 1377-1379.

Pike, A., MacKinnon, D., Cumbers, A., Dawley, S., \& McMaster, R. (2016). Doing evolution in economic geography. Economic Geography, 92(2), 123-144.

Qian, G., Khoury, T. A., Peng, M. W., \& Qian, Z. (2010). The performance implications of intra-and inter-regional geographic diversification. Strategic Management Journal, 31(9), 1018-1030.

Rahmouni, O. (2020). The impact of the geographical diversification of Saudi exports: An intensive and extensive margin approach. Asian Economic and Financial Review, 10(10), 1077-1087.

Sandoval, M. F. L., Robertsdotter, A., \& Paredes, M. (2017). Space, power, and locality: The contemporary use of territorio in Latin American geography. Journal of Latin American Geography, 16(1), 43-67.

Sarstedt, M., \& Cheah, J.-H. (2019). Partial least squares structural equation modeling using SmartPLS: A software review. Journal of Marketing Analytics, 7(3), 196-202.

Simandan, D. (2011). Is engaged pluralism the best way ahead for economic geography? Commentary on Barnes and Sheppard (2009). Progress in Human Geography, 35(4), 568-572.Available at: https://doi.org/10.1177/0309132510390874.

Van den Burg, S. W., Aguilar-Manjarrez, J., Jenness, J., \& Torrie, M. (2019). Assessment of the geographical potential for couse of marine space, based on operational boundaries for Blue Growth sectors. Marine Policy, 100(12), 43-57.

Wakaisuka-Isingoma, J., Aduda, J., Wainaina, G., \& Mwangi, C. I. (2016). Corporate governance, firm characteristics, external environment and performance of financial institutions in Uganda: A review of literature. Cogent Business $\mathcal{E}^{\circ}$ Management, 3(1), 126-138.

Wills, J. (2019). The geo-constitution: Understanding the intersection of geography and political institutions. Progress in Human Geography, 43(3), 416-435.Available at: https://doi.org/10.1177/0309132518768406.

Xu, J., Yang, M., Hou, C., Lu, Z., \& Liu, D. (2020). Distribution of rural tourism development in geographical space: A case study of 323 traditional villages in Shaanxi, China. European Journal of Remote Sensing, 4(1), 1-16.

Zúñiga-Vicente, J. Á., Benito-Osorio, D., Guerras-Martín, L. Á., \& Colino, A. (2019). The effects of international diversification on the link between product diversification and performance in a boom and bust cycle: Evidence from Spanish firms (1994-2014). Journal of International Management, 25(4), 100687.Available at: https://doi.org/10.1016/j.intman.2019.100687. 